\title{
U.S. Energy Independence With Lower Emissions
}

Wes Williams, Sam Houston State University, USA

Balasundram Maniam, Sam Houston State University, USA

Geetha Subramaniam, Universiti Teknologi MARA, Malaysia

\begin{abstract}
Energy Independence as well as concern for carbon emissions are policy topics that have been frequently discussed on the public stage. This paper analyzes the possibility of creating an energy portfolio that will achieve energy independence while reducing carbon emissions and how that portfolio is likely to change over time. Domestic oil, hydrogen fuels, domestic natural gas, hydropower, wind power, solar power, and nuclear power are the fuels discussed to make up the energy portfolio that will eliminate the United States dependence on foreign oil while reducing the carbon emissions generated during the production of energy.
\end{abstract}

Keywords: Energy Independence; Lower Emissions; Foreign Oil; Alternative Energy Sources

\section{INTRODUCTION}

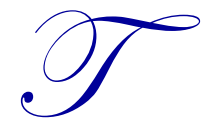

he United States relies heavily on other countries to supply much of the energy we use. This problem exposes the United States to financial risk as well as national security risk. The solution to this problem is one that is easily stated yet difficult to achieve. Energy independence is an answer. However, this energy independence is not enough. The United States should not be happy with merely producing $100 \%$ of the energy we use domestically; the United States should strive for $100 \%$ domestically produced energy supply while lowering carbon emissions. The main energy import for the United States is crude oil, which is used to develop many products. The United States consumes about 18.8 million barrels of oil per day while producing only about 9.1 million barrels of oil per day (Smith, 2011). Logic tells us that if crude oil is the United States' number one energy import, we need to produce more oil domestically. However, this is only a short term solution which will not help the secondary goal of lowering carbon emissions. To fully succeed in the goal of energy independence, the United States will have to produce more oil domestically in the short run while exploring domestic options to replace oil as an energy source for the future. In order to replace oil as an energy source, alternatives for all products that are currently derived from oil must be developed.

Currently one barrel of crude oil makes approximately 19.36 gallons of gasoline, 10.04 gallons of diesel, 6.80 gallons of petrochemicals, 3.91 gallons of jet fuel, 1.72 gallons of liquefied petroleum gases, 1.68 gallons of heavy fuel oil, and 1.24 gallons of other distillates (Department of Energy, 2011). Developing renewable replacements for each of these products will not only reduce the demand for oil but will also open the possibility to reduce the energy used to derive these products. The petroleum refining subsector accounts for $96 \%$ of the US petroleum and coal products industry's energy consumption (Ozalp, Hyman, 2007).

The other piece of the energy puzzle that must be addressed in order to reduce carbon emissions and other pollutants is coal fired power plants and coal used in industrial processes. Coal produces 208,000 pounds of carbon dioxide, 208 pounds of carbon monoxide, 457 pounds of nitrogen oxides, 2,591 pounds of sulfur dioxide, 2,744 pounds of particulates, and 0.016 pounds of mercury per billion Btu of Energy input (NaturalGas.org, 2011). These figures for coal pollutants put coal high on the list of energy sources to replace in order to lower carbon emissions. 


\section{US ENERGY INDEPENDENCE WITH LOWER EMISSIONS}

The objective of the study is to provide possible solutions for energy independence and reducing the amount of carbon emissions. The study will show that in the short term, energy independence can be achieved by opening domestic oil supplies to drilling and utilizing the abundant domestic natural gas supply, which also produces fewer carbon emissions than oil, in place of oil imports. Hydrogen fuel is explored as an energy source for transportation that can contribute in the future to a reduced dependence on oil as well as lower carbon emissions than oil. Energy fuels that can contribute to the United States energy demand in both the short and long term that produces zero carbon emissions are hydropower, wind, and solar power. Nuclear fusion will be shown to be a key to U.S. energy independence. Nuclear fusion has the added benefit of producing nearly zero carbon emissions.

\section{Domestic Oil}

The phrase often touted by politicians, "drill here, drill now," could be a short term solution for energy independence if we can find about 9.7 million barrels per day of oil reserves domestically (Smith, 2011). The good news is that the United States has a large amount of oil reserves. The bad news is that there are many political and environmental obstacles to bring much of this oil to the surface. Most new oil discoveries are unconventional and located in shale formations. They require horizontal drilling and "fracking" to uncover. Some are located under restricted lands. The horizontal drilling and "fracking" involves drilling a vertical hole to the depth where the oil bearing shale is located, then drilling horizontally through the shale. As the well is drilled, it is also cased with steel pipe and cement. Once the well has been drilled, perforating charges are placed into the bore hole and detonated to create holes in the horizontal section of the casing pipe several thousand feet below the surface. After the casing pipe has been perforated, the fracking solution, which consists of a high volume of water, is pumped into the well at extremely high pressure in order to create many cracks in the shale formation which will release the crude oil that has been trapped there for millions of years. This process has caused debate in some areas of the country about the safety of the ground water these wells drill through in order to reach the depth of the oil rich shale. One of the newest of these shale formations is known as the Eagle Ford Shale, located in south Texas. The recoverable oil potential for Eagle Ford shale is around 4.7 billion barrels if only $3 \%$ of the oil is recovered from the shale formation and $30 \%$ of the oil is usually recovered from a well. Every $1 \%$ extraction gained from improved extraction techniques will yield another 1.6 billion barrels of oil (Badiali, 2010). One of the other big shale plays recently discovered is located in Montana and North Dakota. It stretches into Canada and is called the Bakken formation. The United States Geological Survey (USGS) estimated the Bakken formation to hold 3.0 to 4.3 billion barrels of technically recoverable oil using today's technology (USGS, 2008). Much of the drilling activity on the United States portion of the Bakken formation lies beneath the Blackfeet Indian Reservation that makes getting actual results of drilling activities difficult (Brown, 2011).

While the two shale formations discussed above represent a large and growing domestic supplies of oil, the largest domestic oil reserves are owned by the federal government. Various regulations make that oil inaccessible for the most part. In 2008, the U.S. Department of Interior's Bureau of Land Management produced a report that stated that there are 279 million acres under federal management where oil and gas could potentially be extracted. The total onshore oil resource is about 31 billion barrels, $62 \%$ of which is inaccessible. Only $8 \%$ of the 31 billion barrels of onshore oil supply controlled by the federal government is accessible under the standard lease terms. The largest untapped land-based oil deposit in the United States is located within the Arctic National Wildlife Refuge, which is currently off-limits to drilling. It is estimated to hold approximately 7.7 billion barrels of oil. 85.9 billion barrels of oil lie offshore but expansion of offshore oil recovery is off-limits as well (Winn, 2008). Federal Government policy resulting from the $2010 \mathrm{BP}$ oil spill has slowed exploration and oil production on offshore lands that were not previously restricted. While there are new discoveries and increased access to oil deposits through technological advances and a large supply of oil deposits under government controlled land, there are several hurdles to overcome before the United States can produce enough oil domestically to be $100 \%$ energy independent. If the United States cannot drill its way into energy independence, alternatives to oil must be found. One of those alternatives is hydrogen. 


\section{Hydrogen}

The use of hydrogen to power personal transportation vehicles requires technology that has yet to be fully developed. However, once this technology is fully developed, hydrogen vehicles could significantly decrease the amount of demand for gasoline (Tseng, Lee \& Friley, 2005). In addition to decreasing the demand for gasoline, energy security will improve due to supply diversification. Emissions would also decline with the transition to hydrogen-fueled vehicles from petroleum fueled vehicles. An important implication of demand dropping for gasoline is lower need throughout for petroleum refineries and a resulting higher price for other petroleum based products. This statement describes the importance of finding replacements for all products produced from oil. In order for hydrogen vehicles to begin to reduce the demand for gasoline, hydrogen production facilities must be developed to produce hydrogen fuel from feedstock such as coal, natural gas, biomass, or electrolysis (Tseng, Lee, Friley, 2005). Harvesting hydrogen from natural gas or coal could produce by products that may be useful replacements for some petrochemicals. Transportation systems such as pipelines must be put in place to move the hydrogen fuel from the production facility to the demand center and vehicles must be produced to operate on the hydrogen fuel. All of this must take place at a total cost that is less than the cost associated with purchasing and operating a conventional fueled vehicle, otherwise economic theory indicates consumers will not purchase the vehicle and there will be no demand for the hydrogen fuel.

The shift to a hydrogen fueled vehicle may be becoming a more distant future possibility than a shorter term solution. A research collaboration involving the Department of Energy, the U.S. Council for Automotive Research, five major energy companies, and two electric utilities called FreedomCAR and Fuel Partnership supports continued research and development for hydrogen and fuel cells as part of their R\&D portfolio along with technologies that could be ready in the nearer future (Fuel Cells Bulletin, 2010). While the academics suggest the importance of continued research in hydrogen fuels, the Department of Energy had proposed to cut the funding for the Hydrogen and Fuel Cell Technologies program by more than 40\% in fiscal year 2012 (Fuel Cells Bulletin, 2011). Hydrogen fuel cells could be a future alternative that produces fewer carbon emissions to petroleum powered automobiles, but that alternative may be growing more distant.

Natural gas could be a shorter term solution that could help bridge the gap between petroleum powered and hydrogen powered automobiles as well as being a fuel for producing electricity and heat.

\section{Natural Gas}

Natural gas is perhaps the quickest and relatively easiest fuel choice to bridge the United States from a nation dependent upon oil exporting countries to a nation that produces its own energy. While natural gas is still a fossil fuel and there is a finite supply, the United States has an abundant supply that could be used to reduce our dependency on foreign oil. Natural gas can be found in several types of formations. Conventional deposits are usually gas fields or oil reservoirs that are typically found in highly porous rocks like sandstone (Deutch, 2011). These types of gas deposits only require producers to tap into the formation and the natural pressure of the gas will force it to the surface. Unconventional gas comes from a variety of forms. Tight gas refers to natural gas found in relatively impermeable rock formations, which release gas slowly. Coal-bed methane is gas that has been absorbed into coal seams. Methane hydrate is natural gas in a crystalline solid state that can be found on the ocean floor and in the arctic but is much more difficult to extract than the other forms. The type of unconventional gas that has been surging in recent years is natural gas found between layers of shale formations, which are made of fine-grained sedimentary rock. Once extracted unconventional natural gas is identical to conventional natural gas and can be transported by pipelines or condensed into a liquid and exported internationally (Deutch, 2011). The technology used to extract shale gas is very similar to that used to extract oil from shale, horizontal drilling and hydraulic fracturing or "fracking." The average cost of producing natural gas from shale varies from region to region but tends to range between $\$ 2$ and $\$ 3$ per thousand cubic feet of gas, which is about one-half to one-third the production cost associated with producing natural gas from North American conventional wells (Deutch, 2011). Due to the young technology associated with recovering natural gas from shale plays, there are opportunities for reducing the extraction cost further with operating experience and additional technical advancements. The largest shale plays across the United States are the Marcellus in New York and Pennsylvania, the Barnett and Haynesville in Texas, and the Bakken in North Dakota and Montana (Kargbo, Wilhelm, Campbell, 2010). Technically recoverable, using 
today's technology without considering economic constraints, natural gas reserves from shale is estimated to be in the 600 to 700 trillion cubic feet range out of a total of 2,500 trillion cubic feet of technically recoverable natural gas from all sources (Deutch, 2011).

The shift from oil to natural gas is a shift that could be made in a much shorter time frame than a shift to renewable type energy sources. There is an economic incentive for using natural gas over oil in the United States as oil is three times more costly than natural gas at about $\$ 12$ per million Btu for oil and $\$ 4$ per million Btu for natural gas (Deutch, 2011). Natural gas has another added benefit over oil in being a cleaner burning fuel. Natural gas releases 117,000 pounds of carbon dioxide per billion Btu of energy input whereas oil emits 164,000 pounds of carbon dioxide per billion Btu of energy input (NaturalGas.org, 2011). A nearly 29\% carbon dioxide emission reduction is achieved just by switching fuel source from oil to natural gas. This is just the reduction from burning these fuels. When the emissions from transportation are factored in, natural gas is an even bigger winner in carbon dioxide emissions over oil. Natural gas emits fewer other pollutants than oil as well, such as nitrogen oxides, sulfur dioxide, and mercury (NaturalGas.org, 2011). The challenge for natural gas to replace oil as the primary fuel for transportation is similar to challenges faced by other alternatives to oil, the refueling infrastructure. This hurdle is easily overcome by fleet service vehicles that operate in a designated area and can be refueled centrally. Many U.S. cities have begun converting buses and other city vehicle to run on compressed natural gas instead of diesel or gasoline due to the lower cost and emission benefits received. The lack of refueling stations is a somewhat more difficult hurdle for the conversion of personal vehicles from gasoline or diesel to compressed natural gas though not as difficult as it may seem at first look. Many homes have natural gas service, and there are existing natural gas pipelines running under virtually every city. Though an economically viable solution has yet to be discovered, the possibility of installing refueling stations in homes with natural gas service and at service stations alongside gasoline pumps, is not out of the realm of possibility.

In order to reduce its dependence on foreign oil, the United States must not only replace some of the gasoline and diesel consumption but also replace other products oil is used to make. Economic pressures could spur the development of new processes in the chemical sector to incorporate natural gas instead of oil in the production of polymers, plastics, and other petrochemicals. This economic pressure would almost certainly come with the wide scale transition of transportation fuel to natural gas from oil, reducing the demand for gasoline and diesel. This would reduce overall demand for oil and create a shortage of oil for the chemical sector uses.

Electric power generation and industry is another area where natural gas has huge potential to replace fuel oil as a peaking fuel. It reduces demand for another product produced from oil, and coal as a base load fuel, which provides an opportunity to reduce fewer greenhouse gas emissions. According to the Energy Information Administration's 'Emission of Greenhouse Gases' report in December 2009, 81.3\% of greenhouse gas emissions in the Unites States came from energy-related carbon dioxide. Natural gas is the cleanest of all fossil fuels (NaturalGas.org, 2011). While natural gas could reduce the emission of the greenhouse gas carbon dioxide by almost $30 \%$ when replacing oil and just under $45 \%$ when replacing coal, methane itself is a much more harmful greenhouse gas in terms of its ability to trap heat. While methane emissions account for only $1.1 \%$ of U.S. greenhouse gas emissions, when weighed by global warming potential, methane emissions account for $8.5 \%$ of the greenhouse gas emissions (NaturalGas.org, 2011). Methane emissions occur from the waste management industry, agricultural industry, and leaks from the oil and gas industry. A study was conducted by the Environmental Protection Agency and the Gas Research Institute to determine if potential increase in methane emissions would outweigh any reduction in carbon dioxide emissions resulting from natural gas replacing coal and oil as a fuel source for electric power generation. The conclusion from this study shows the reduction in carbon dioxide and other greenhouse gasses from increased natural gas usage would far outweigh the potential negative effects of increased methane emissions. Researchers from Carnegie Mellon University released a report in 2011 showing natural gas wells in the Marcellus region emit $20 \%$ to $50 \%$ less greenhouse gases than coal used in electric power generation. Natural Gas is an alternative to petroleum products as well as coal that reduces carbon emissions, but it is still a fossil fuel and has a finite supply. Natural Gas cannot be viewed as the long term answer to United States energy independence. Hydropower is not a fossil fuel and can contribute to both short term and long term energy independence for the U.S. 


\section{Hydropower}

Traditional hydropower results from building large dams across rivers that produce a large amount of power with no carbon emissions. However, there is a significant impact in the size of the generation facility footprint and there are potential negative impacts on fishery resources as well as river ecosystems. A win-win solution of producing clean energy while minimizing the impact of the generation facility footprint, negative impacts on fishery resources and river ecosystems is small scale hydropower with generation capacities of $30 \mathrm{MW}$ or less per site (Kosnik, 2010). The Department of Energy conducted an analysis of every two-mile stream segment in 2004. This analysis identified nearly 500,000 viable sites for small scale hydropower capable of providing more than 100,000 MW of power, which represents about 10\% of 2009 electrical generation capacity and $80 \%$ of 2009 renewable generation capacity (Kosnik, 2010). In order to develop small scale hydropower and be able to compete economically with fossil fuel power plants, the cost of development must be around $\$ 2,000$ per Kw or less (Kosnik, 2010). If legislation is passed putting a price on carbon emissions as proposed in The American Clean Energy and Security Act of 2009, small scale hydropower development will become economical even at higher development costs since there is no carbon emissions associated with hydropower. Small scale hydropower will not be able to replace fossil fuel power plants but there are situations where they can compete economically and contribute to the reduction of overall emissions. Wind power is another piece of the energy independence puzzle that can be applied to short and long term solutions.

\section{Wind}

Wind energy fits nicely as a solution to help reduce greenhouse gas emissions. Wind power is derived by converting wind energy into rotational energy and harnessing that rotational energy with electricity generators. This process does not require the burning of any type of fossil fuel and does not emit any greenhouse gasses. While wind power is great source of emission free energy, there is not enough supply of wind power to supply the entire United States electricity demand. While wind power cannot meet the entire U.S. electric demand, the American Wind Energy Association has challenged the wind power industry to grow to meet $20 \%$ of the U.S. electricity needs by 2030 (Levesque, 2007). Large wind generation facilities do face some challenges in their future growth. Many of the areas where wind power generation is feasible are far away from any transmission lines. Transmission companies are hesitant to build transmission lines to areas where there is not currently any electricity generation or demand while wind power companies are hesitant to build wind power generation facilities where there are no transmission lines to take the electricity generated to the demand centers. It is estimated that achieving $20 \%$ of electric power supply from wind power would require an investment of around $\$ 500$ billion in wind power project development and transmission (Levesque, 2007). The wind turbine manufacturing industry is struggling to keep up with the growing demand for wind power components globally. The global market for wind turbines was growing at a rate of $25 \%$ in 2007, which was faster than anticipated, causing a strain on the entire supply chain among component manufacturers. Another of the challenges wind power faces is the tendency for low electricity output from wind during peak electricity demand so the electricity generation capacity mix comprising $80 \%$ of electricity demand would have to be able to provide sufficient power during peak demand while wind power is used as a portion of base load power. The advantage of producing no emissions may help wind energy overcome some of these obstacles with increasing regulation and pressure to limit greenhouse gas emissions by federal and state governments.

While wind turbines for utility use experience the hurdle of a lack of transmission lines, small wind turbines, typically 3 to $10 \mathrm{~kW}$, used to power homes, farms, or small businesses can be installed on premises without the need of transmission lines. Small wind turbines require less wind to operate than large scale utility turbines so they can produce power in areas that comprise more than 50\% of the United States (Unknown, 2003). Technological advances have made small wind turbines quieter and reduced the cost to less than half that of a comparative solar photovoltaic panel system. Small wind turbines become even more economical for areas with high electricity rates and government incentives making the payback period as short as 5 to 7 years for a system with a 30 year life and cost of around $\$ 16,000$ to $\$ 20,000$ (Unknown, 2003). The biggest obstacle small wind turbines face is local government height restrictions. Hydrogen, hydropower and wind power are not enough to meet the long term energy demands of the United States, so solar must be added to the mix for long term energy independence in the U.S. with lower carbon emissions. 


\section{Solar}

The sun is a great source of energy that people have used for centuries. Solar energy does not require fossil fuels and does not emit greenhouse gas. Solar power plants capture the suns energy through photovoltaics where it is converted to electricity. The high cost of producing the photovoltaics and the intermittent tendency of solar power has kept this energy source from coming into widespread use in the past. However, recent cost reduction in the production of photovoltaics could enable solar technologies to become more cost competitive with fossil fuel generated electricity. Large areas of vacant land with a high amount of solar radiation, like the desert areas of southwest United States, are necessary for a large solar power facility. With a limited geographical area suitable for large scale solar power facilities, large capacity transmission lines would be required to make power produced in the southwest available for all regions of the United States. Even with transmission lines in place, solar power does not answer the full need of the United States electricity supply since it is only available during times when the sun is out with little cloud cover. One answer proposed to solve this problem is combining solar power with compressed air energy storage. This would utilize natural reservoirs beneath the surface of the earth to store pressurized air, much like natural gas storage facilities, which can be released to power turbines when solar power is not available (Fthenakis, Mason, Zweibel, 2009). This solution would require a vast amount of compressed air storage capacity, which has not been identified. Solar power again seems to be a piece of the puzzle but not the entire solution for the short to medium term at least.

The reduced cost of producing photovoltaics along with the publicity and more widespread knowledge of solar power has made small scale solar power more popular for residential applications. While more expensive than wind power, there is no need for solar panels to placed high in the air. Solar panels can be used any place where there is sufficient exposure to the sun, making them convenient to install on the roofs of homes. While these panels only supply intermittent power and are generally not enough to supply a home's entire demand load, even with storage batteries, they can reduce the amount of power used from grid supply. Personal solar power use is popular for those who are willing to pay a bit more for their electricity in order to reduce their carbon footprint, but they are still not economically feasible due to their relatively long payback period compared to the useful life of the system (Fthenakis, Mason, Zweibel, 2009).

Bringing each of the non-fossil fuel pieces of the energy puzzle together is probably not going to be enough to meet the long term power demands for the United States. Nuclear power is needed to complete the energy independence puzzle.

\section{Nuclear}

Nuclear power can produce large amounts of energy with no greenhouse gas emissions. Typically the energy from nuclear reactions is used to heat water in order to generate steam, which is used to turn turbine electrical generators. Once the steam passes through the turbine, it is condensed back into liquid form and sent back to the boiler so the process can be repeated. There are two ways usable energy can be generated from nuclear power, fission and fusion.

Nuclear fission is widely used today and makes up about $6 \%$ of the world's energy requirements (Loyn, 2011). Fission occurs when a large isotope of a radioactive element is split apart by a neutron into two smaller elements and three more neutrons. This split creates a chain reaction and generates energy. There are a few drawbacks when using nuclear fission as an energy source. First, nuclear fission produces a large amount of harmful waste that must be stored safely for as much as 10,000 years. The fuel used in the fission process is uranium, which has a finite supply and does not occur in great concentrations. This makes uranium mining costly. Also, there are great concerns about the possibility of the release of radiation if nuclear power plants are damaged. This happened recently when an earthquake and tsunami hit Japan in March 2011. Unfortunately, nuclear fission reactors cannot meet the full electrical demand. They have major implications of hazardous waste and a limited fuel supply, making it impractical for a replacement to fossil fuels for electric power generation.

Nuclear fusion occurs when the nuclei of two atoms are joined together releasing energy. This process is achieved by shooting two atoms at each other, shooting one atom at a stationary atom, or super heating the atoms to 
overcome the static repulsive forces produced by the protons, allowing the attractive forces of the neutrons to join together (Loyn, 2011). The technology to produce these reactions for use in civilian energy production has not yet been perfected. The military, however, has used this technology to create the hydrogen bomb, which contains a fission reaction for the initial energy to make the fusion reaction and a final fission reaction which produced about 500 times more energy than the first fission weapons (Loyn, 2011). The hydrogen bomb example illustrates the amount of energy possible from a fusion reaction if it can be stabilized and controlled. Researchers are getting closer to making fusion reactor power plants a reality. The National Ignition Facility in the United States is expected to have ignition of controlled thermonuclear reactions in 2012. However, the indirect drive scheme chosen for the National Ignition Facility will achieve limited energy gains, which are not sufficient for energy production on nuclear fusion power plants (Tikhonchuk, Mima, 2011). Nuclear fusion power plants are the key to not only the United States' energy future, but the world's as well. Nuclear fusion provides more energy than nuclear fission without the harmful waste and the technology to make nuclear fusion power plants a reality is just on the horizon. The first nuclear fusion power station is estimated to be built by 2018, which will completely change the discussion of how the United States, and the rest of the world, powers its future (Loyn, 2011). Nuclear fusion could complete the energy mix for long term energy independence in the United States while producing much fewer carbon emissions than what is produced in today's energy sector.

\section{IMPLICATION FOR THE FUTURE}

The implications for the United States not acting, remaining dependent on foreign oil and emitting dangerously high levels of greenhouse gases are immense. By being dependent on foreign oil, the U.S. exposes its leaders to make foreign policy decisions based on what country is supplying our oil and who we need to make happy to keep that oil supply coming. This scenario is a very dangerous one that could potentially compromise the values the United States has stood behind for over 200 years. Another danger that the U.S. dependency on foreign oil poses are the risks to financial exposure and price setting by countries not bound by our laws. Foreign dependence on oil is only half the problem. If the United States continues to pump the levels of greenhouse gases into the atmosphere at the current rates, devastating and rapid climate change could be the result.

There are many options the United States can choose to power the future. The only part that is completely clear is that the current U.S. energy portfolio is not sustainable. The best solution is likely a combination of alternatives that will gradually take the place of oil and eventually all fossil fuels.

The approach to energy independence must be approached in phases. The first phase to reduce our dependence on foreign oil is by looking at the regulations, considering the latest technologies, which make it impossible for companies to drill on certain federal lands, and determine if these regulations should be altered in light of new drilling technologies and practices. The second step to the first short term phase is to substitute natural gas wherever possible, replacing the scarce oil resource with a domestically plentiful natural gas resource. In the short term, reducing greenhouse gases can be achieved by replacing oil fuels with natural gas, and replacing coal fired power with natural gas fired power plants and small scale hydro power plants. Incentives should also be provided to make small wind turbines even more economical to own and produce. The second phase involves the introduction of hydrogen fuel cell vehicles and a refueling infrastructure that would combine large scale wind with solar power plants and infrastructure, reducing further the nation's dependence on fossil fuels. The final long term phase involves moving completely to renewable energy sources including nuclear fusion, wide scale use of personal and public wind, solar energy and any other renewable energy source technological advances bestowed upon mankind.

\section{SUMMARY AND CONCLUSION}

The United States depends mainly on foreign countries for oil as part of the current energy portfolio. This oil produces a large amount of carbon emissions. The U.S. wants and needs to be energy independent and reduce harmful carbon emissions into the atmosphere. The shortest term solution, of opening up domestic oil fields in order to reduce oil imports, contributes to the goal of energy independence but does not help in the reduction carbon emissions. Additionally, natural gas can be used to decrease the use of domestically produced oil to reduce and possibly eliminate oil imports. This would also contribute to lowering carbon emissions. The use of hydrogen as an 
energy fuel source is an important research topic that may help replace petroleum as a fuel for automobiles while reducing the greenhouse gas emissions that come from petroleum fueled automobiles. Hydro, wind, and solar power are each renewable energy sources that can contribute both in the short term and long term to the energy independence goal and each fuel source contributes to the secondary goal of reducing carbon emissions. Nuclear fusion is a technology that promises to be a large scale energy producer that completes the long term energy portfolio of the future. The long term energy portfolio will achieve the primary goal of energy independence as well as a significant reduction in carbon emissions by the use of renewable energy sources.

\section{AUTHOR INFORMATION}

Mr. Wes Williams holds a MBA from Sam Houston State University and has presented several papers in the area of finance.

Dr. Balasundram Maniam is a Professor of Finance at Sam Houston State University. He has published numerous referred journals articles. He is currently serving as the editor, associate editor and editorial board member of several

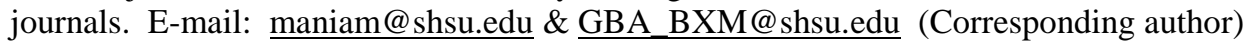

Dr. Geetha Subramaniam is a senior lecture at Universiti Technologi Mara, Malaysia. She has published numerous referred journals articles.

\section{REFERENCES}

1. Badiali, M. (2010, November 17). The largest U.S. oil discovery since Prudhoe Bay. The Growth Stock Wire. Retrieved November 19, 2011, from http://www.growthstockwire.com/2562/The-Largest-U-S-OilDiscovery-Since-Prudhoe-Bay

2. Brown, D. (2011, June). Western Montana Bakken in play. AAPG Explorer. Retrieved November 19, 2011, from http://www.aapg.org/explorer/2011/06Jun/bakken 0611.cfm

3. Bryan, P. (2011, October 19). The how's and why's of replacing the whole barrel. Retrieved November 19, 2011, from http://energy.gov/articles/hows-and-whys-replacing-whole-barrel

4. Churchill, J. (2000, November 13). Oil consumption in North America. Retrived November 19, 2011, from http://maps.unomaha.edu/peterson/fund/sidebar/oilconsumption.html

5. $\quad$ Deutch, J. (2011). The good news about gas. Foreign Affairs, 90(1), 82-93.

6. D'haeseleer, W. (2003).The importance of fusion development towards a future energy source. Fusion Engineering and Design, 66, 3-15.

7. Fthenakis, V., Mason, J., Zweibel, K. (2009). The technical, geographical, and economic feasibility for solar energy to supply the energy needs of the US. Energy Policy, 37(2), 387-399.

8. Jaffe, A. (2011). The Americas, not the Middle East, will be the world capital of energy. Foreign Policy, 188, 1-3.

9. Kargbo, D., Wilhelm, R., Campbell, D. (2010). Natural gas plays in the Marcellus shale: challenges and potential opportunities. Environmental Science \& Technology, 44(15), 5679-5684.

10. Kosnik, L. (2010). The potential for small scale hydropower development in the US. Energy Policy, 38(10), $5512-5519$.

11. Levesque, C. (2007). Windpower 2007 shatters all records. Renewable Energy Focus, 8, 38-40.

12. Loyn, C. (2011). Can nuclear power save the climate? Young Scientists Journal, 4(9), 16-19.

13. Ozalp, N., \& Hyman, B. (2007). Allocation of energy inputs among the end-uses in the US petroleum and coal products industry. Energy, 32(8), 1460-1470.

14. Smith, C. (2011). We're no. 1 (and no. 3)! Surprising facts about the US and oil. Daily Finance. Retrieved November 19, 2011, from http://www.dailyfinance.com/2011/02/28/surprising-facts-about-us-and-oil/

15. Tikhonchuk, V., Mima, K. (2011).Alternative schemes for the inertial fusion energy. Fusion Engineering \& Design, 86(6-8), 504-508.

16. Tseng, P., Lee, J., \& Friley, P. (2005). A hydrogen economy: opportunities and challenges. Energy, 30(14), 2703-2720.

17. Winn, P. (2008, June 7). U.S. policies put most U.S. oil off-limits to drilling. CNSNews.com. Retrieved November 19, 2011, from http://www.cnsnews.com/news/article/us-policies-put-most-us-oil-limits-drilling 
18. Zhang, H., Zhou, D., Cao, J. (2011). A quantitative assessment of energy strategy evolution in China and US. Renewable and Sustainable Energy Reviews, 15(1), 886-890.

19. Unknown (2008, April 10). 3 to 4.3 billion barrels of technically recoverable oil assessed in North Dakota and Montana's Bakken Formation - 25 times more than 1995 estimate. Retrieved November 19, 2011, from http://www.usgs.gov/newsroom/article.asp?ID=1911

20. Unknown (2003). Small wind turbines: can they live up to their potential in the US? Refocus, 4(4), 40-44.

21. Unknown (2011).Natural gas and the environment. Retrieved November 19, 2011, from http://www.naturalgas.org/environment/naturalgas.asp

22. Unknown (2010). US academics support continuing fuel cells, hydrogen tech research. Fuel Cells Bulletin, $2010(8), 11$.

23. Unknown (2011). US plans to cut fuel cells, hydrogen budget in 2012. Fuel Cells Bulletin, $2011(2), 1$. 


\section{NOTES}

